\title{
Fermilab
}

Managed by Fermi Research Alliance, LLC for the U.S. Department of Energy Office of Science

\section{A New PIT Nb3Sn Process Toward Improved Cost- Performance for HEP High Field Magnets}

\section{Cooperative Research and Development Agreement Final Report}

\section{CRADA Number: FRA-2006-0004}

\section{Fermilab Technical Contact: Victor Yarba}

Summary Report

4 March 2008 


\section{NOTICE}

This report was prepared as an account of work sponsored by an agency of the United States government. Neither the United States government nor any agency thereof, nor any of their employees, makes any warranty, express or implied, or assumes any legal liability or responsibility for the accuracy, completeness, or usefulness of any information, apparatus, product, or process disclosed, or represents that its use would not infringe privately owned rights. Reference herein to any specific commercial product, process, or service by trade name, trademark, manufacturer, or otherwise does not necessarily constitute or imply its endorsement, recommendation, or favoring by the United States government or any agency thereof. The views and opinions of authors expressed herein do not necessarily state or reflect those of the United States government or any agency thereof.

Available electronically at http://www.osti.gov/bridge

Available for a processing fee to U.S. Department of Energy and its contractors, in paper, from:

U.S. Department of Energy Office of Scientific and Technical Information

P.O. Box 62

Oak Ridge, TN 37831-0062

phone: 865.576 .8401 fax:

865.576 .5728

email: mailto:reports@adonis.osti.gov

Available for sale to the public, in paper, from:

U.S. Department of Commerce

National Technical Information Service

5285 Port Royal Road

Springfield, VA 22161 phone:

800.553.6847

fax: 703.605 .6900

email: orders@ntis.fedworld.gov_online

ordering: http://www.ntis.gov/ordering.htm 
In accordance with Requirements set forth in Article XI.A(3) of the CRADA document, this document is the final CRADA report, including a list of Subject Inventions, to be forwarded to the Office of Science and Technical Information as part of the commitment to the public to demonstrate results of federally funded research.

CRADA number:

CRADA Title:
FRA-2006-0004

A New PIT Nb3Sn Process Toward Improved Cost-Performance for HEP High Field Magnets

Parties to the Agreement: SupraMagnetics, Inc and Fermi Research Alliance, LLC

\section{Abstract of CRADA work:}

The development of improved, cost-effective Nb3Sn superconductors would have an immediate benefit for high field magnets in High Energy Physics (HEP) applications. This project will develop and demonstrate an economical powder-in-tube (PIT) Nb3Sn process for use in magnets for future HEP accelerator research. In Phase I, a low-cost, intermetallic, phasepure Cu5Sn4 powder was developed, a PIT Nb3Sn process was designed, and prototype Nb3Sn conductors were fabricated. A cost-performance analysis was conducted, which suggested that the approach will meet DOE goals. In Phase II, powder manufacturing will be optimized, and advanced PIT designs will be fabricated on intermediate size billets. The data will be used to assemble and manufacture a scaled-up prototype conductor. Material will be produced and made available for building and testing prototype cables and test magnets at DOE national laboratories.

In addition to HEP applications, an economical Nb3Sn superconductor would have application in high field magnets used in fusion machines and Nuclear Magnetic Resonance (NMR). For fusion machines, a successful demonstration would have enormous economic and social benefits. T

The scope of this CRADA is limited by the term of the Phase II SBIR grant (24 months) to include critical current and magnetization testing of a number of Nb3Sn strand samples, as well as cable fabrication and evaluation to assess and improve strand suitability to plastic deformation.

Funded in part by SBIR grant DE-FG02-07ER84381.

\section{Summary of Research Results:}

We have introduced a new process utilizing Cu5Sn4 powder as a potential low-cost approach for the PIT process. Preliminary PIT wire with Cu5Sn4 cores show good 
processing and drawing characteristics. Filament diameters on the order of 25 micron have been achieved in prototype conductor designs. Heat treatment at $675 \mathrm{oC}$ for times up to 60 hours resulted in thick A15 layers of about 10 micron with corresponding grain size of 100 $\mathrm{nm}$ to $200 \mathrm{~nm}$.

Short sample critical currents were measured at various applied magnetic fields from $10 \mathrm{~T}$ to $15 \mathrm{~T}$ at Fermi National Laboratory. The non-Cu Jc in sample wires presented in this work were $1855 \mathrm{~A} / \mathrm{mm} 2$ to $2037 \mathrm{~A} / \mathrm{mm} 2$ at $12 \mathrm{~T}$. The corresponding n-values were on the order of 50 . These results are presented in Figure 7 . The critical temperature, Tc, was 18K. These measurements were performed at Brookhaven National Laboratory. In comparison to previous work on PIT Nb3Sn conductors with NbSn2 cores, [10] the present performance characteristics as shown in Figure 7 are comparable. Moreover, the new PIT approach with the Cu5Sn4 cores promise lower materials and processing costs.

\section{Related Reports, Publications, and Presentations:}

L. R. Motowidlo et al. "A Nb3Sn Conductor via CU5SN4 PIT Process for High Field Applications", Advances in Cryogenic Engineering: Transactions of the International Cryogenic Materials Conference, vol. 54, p. 269, Jul. 16-20, 2007. cited by applicant.

AIP Conference Proceedings 986, 269 (2008); Motowidlo, L.R. and Ozeryansky, G.M., “A NB 3 SN Conductor via CU5SN4 PIT Process for High Field Applications",

https://doi.org/10.1063/1.2900355

Leszek R. Motowidlo. A New PIT Nb3Sn Process, Toward Improved Cost-Performance for HEP High Field Magnets. United States: N. p., 2012. Web. (OSTI Identifier: 1037616)

\section{Subject Inventions listing:}

None

Report Date: 4 March 2008

Technical Contact at Fermilab: Victor Yarba

This document contains NO confidential, protectable or proprietary information. 